Anru Lee, In the Name of Harmony and Prosperity. Labor and Gender Politics in Taiwan's Economic Restructuring Catherine Farris, Anru Lee, Murray Rubinstein (eds.), Women in the New Taiwan. Gender Roles and Gender Consciousness in a Changing Society

New York, State University of New York Press, 2004, 196 p.

Armonk, New York, Londres M.E. Sharpe, 2004, 390 p.

Marina Thorborg

\title{
OpenEdition
}

Journals

Édition électronique

URL : http://journals.openedition.org/chinaperspectives/618

DOI : 10.4000/chinaperspectives.618

ISSN : 1996-4617

Éditeur

Centre d'étude français sur la Chine contemporaine

Édition imprimée

Date de publication : 1 avril 2006

ISSN : 2070-3449

Référence électronique

Marina Thorborg, "Anru Lee, In the Name of Harmony and Prosperity. Labor and Gender Politics in Taiwan 's Economic Restructuring

Catherine Farris, Anru Lee, Murray Rubinstein (eds.), Women in the New Taiwan. Gender Roles and Gender Consciousness in a Changing Society », China Perspectives [En ligne], 64 | march - april 2006, mis en ligne le 21 décembre 2006, consulté le 22 septembre 2020. URL : http://journals.openedition.org/ chinaperspectives/618; DOI : https://doi.org/10.4000/chinaperspectives.618

Ce document a été généré automatiquement le 22 septembre 2020.

(C) All rights reserved 


\section{Anru Lee, In the Name of Harmony and Prosperity. Labor and Gender Politics in Taiwan's Economic Restructuring Catherine Farris, Anru Lee, Murray Rubinstein (eds.), Women in the New Taiwan. Gender Roles and Gender Consciousness in a Changing Society}

New York, State University of New York Press, 2004, 196 p. Armonk, New York, Londres M.E. Sharpe, 2004, 390 p.

Marina Thorborg

1 Two episodes stand out from one of my last research sojourns to Taiwan a few years ago.

2 Episode 1 ! With the factory owner in a textile factory in one of the export processing zones we look at the large empty production halls while he tells me of a disappearing work force. "Two years ago half of the work force left and the same happened again last year. Next year I expect the same if I'm not allowed to import workers! Only R\&D, (Research and Development) and high-end products, such as suede clothes are left," he says with a sigh.

Episode 2 ! I am sitting in a hotel lobby in Taipei with an old Taiwanese friend of mine and some of his colleagues, all male. It is almost 8 p.m. and we are having a drink. Suddenly my friend turns to me and says "Why don't you go and have a nap ?" "A nap, why? The evening has just begun!" I ask. "Well, you're the only woman here and, in addition, a Westerner, so you can't come with us, my colleagues would never ever accept it". So this Taiwanese professor and his friends politely say goodbye to me and leave! 
Both books under review here deal with Taiwan's rapid economic development and how this development has built upon the hard, undervalued labour of young women, just as it did in South Korea ${ }^{1}$, and how with increasing diversification of the economy more and more workers voted with their feet, leaving the least attractive jobs, those with the lowest pay and the longest working hours, such as was typical of the textile industry. This phenomenon occurred in Taiwan ten to fifteen years ago and is beginning to happen in the Pearl River Delta in southern China's Special Economic Zones, and also first in textiles, and for the same reasons ${ }^{2}$.

5 Anru Lee, in her dissertation turned book, has one of her chapters, "Between Filial Daughter and Loyal Sister" already published in the other book under review here. This chapter gives an excellent feminist analysis of how the unequal treatment of daughters is hidden under the cover of the Chinese "corporate family". This chapter on Taiwan is an equivalent to Janet Salaff's important work on working daughters in Hong Kong ${ }^{3}$. Both show the flexibility and adaptability in family structures that basically remain strongly patriarchal and hierarchal benefiting sons at the expense of daughters. Another chapter on "Guests from the Tropics"-also published in Nan Chow Lee's book -deals with how, from the late 1980s, the ban on importing foreign workers was lifted, while simultaneously Taiwanese entrepreneurs began to move their operations overseas. This will explain the first episode above.

6 Rapid industrialisation in Taiwan contributed to an optimistic mood and helped to explain why in Taiwan just as earlier in the United States and as well in Thailand a notion of class-consciousness by workers had a hard time to develop. The ideology of "Black hand becoming boss" (hei shou bian tou jia) meant that everyone working hard enough could one day become a self-made man and boss himself. Therefore many workers were prepared to endure a few hard years. A pervasive structure of small and medium-sized enterprises made this seem even more likely. This ideal was for men only. Research from around the world has shown the worst working conditions precisely in small family-style enterprises, where young women in so-called light industry did the most tedious work ${ }^{5}$. So the place where many, hardworking young men could aspire to be their own boss was also where exploitation of labour was greatest and hitting young women more than men.

7 A central theme of Anru Lee's work is the embeddedness of culture in capitalist development.

8 Some other researchers have termed this East Asian development "hypermasculinisation", showing young, single women as the big losers and questioning this "England-1840-model", asking if this is "development" when large segments of a population, particularly young women, are left out ${ }^{6}$.

9 The same development and similar analysis can be found on women and exportindustrialisation in China showing a patriarchal and hierarchal society joining hands with global capital to the detriment of particularly young female workers ${ }^{7}$.

10 The anthology on Women in New Taiwan not only deals with women and gender roles but as well includes two chapters on male roles with a chapter on "Carousing and Masculinity! The Cultural Production of Gender in Taiwan", by Avron Boretz explaining male bonding in all male groups in all classes of society where only paid hostesses participate, showing a confluence of both Chinese and as well Japanese 
patriarchal legacies, long traditions of sex segregation, and veneration for old age. A woman in such a male group competing in singing and heavy drinking would upset the rules of male bonding and be an embarrassment. Only paid hostesses for sexual titillation would fit in. This will explain episode number two above.

This fits with what is aptly described as typical behaviour of unattached, young men in strictly sex segregated, patriarchal societies in a new study called "Bare Branches" and would according to it in other types of societies be regarded as immature, adolescent conduct not fitting for mature, educated, and attached men ${ }^{8}$.

The chapter on "A Bright Summer Day" by Yu-hsiu Liu in this anthology brings this degrading of women to a logical conclusion by showing clearly that the film with this name is more concerned with the structure of the film then with the murder of a woman. Male relationships are more important and a man becomes a real man only by killing a woman, with sex and killing starkly intertwined. Here Freud is used to the full with some dubious explanations.

13 A most interesting chapter by Ping-chen Hsiung on "Sons and Mothers" is concerned with the practical implications of filial piety, showing that with simple demography few men were ever to practise it as they would most likely be in their teens or early twenties when their parents passed away given the short life expectancy in traditional China.

Hence only in exceptional cases did a son have to take long time care of his parents, particularly his mother. Because of discrimination and frequent and dangerous childbirth men were outliving women. This meant that this ideal was so much easier to uphold as it only exceptionally had to be practised.

Murray A. Rubenstein in her chapter on "Lu Hsiu-lien and the Origins of Taiwanese Feminism"-currently Vice President of Taiwan-shows how influential one person can be, given the right personality and timing. Most often Anette Lu Hsien-Lien has been ahead of her time and by being tolerant and all encompassing has encouraged diversity and co-operation, which has given the Taiwanese women's movement a head-start. This could have been more stressed in this otherwise well-researched and well-written chapter.

In the chapter on, “Women's Liberation Under 'East Asian Modernity' in China and Taiwan Historical, Cultural, and Comparative Perspectives" by Catherine S. P. Farris a few mistakes are made. Firstly on the opening page modernisation is said to contribute to changing traditional views on gender while latest research show that the main change occurs in the transition from industrial to post-industrial society ${ }^{9}$. On page 343 the main reason is not given for why the campaign for the new marriage law during 1950-52 ended. It was because of mass murder, often with the accomplishments of cadres, of women wanting a divorce, meaning those the authorities wanted to help with the new marriage law of May 1st 1950 instead became the victims.

Therefore a new campaign started on Women's Day, March $8^{\text {th }} 1953$, promoting harmonious families, which also of course furthered production, while a divorce would cause land to be split and slow production ${ }^{10}$. On page 366 labour force participation is said to be the highest in advanced socialist countries, (if they still exist?) while in reality it was higher in Scandinavia and without the very negative side effects as in socialist countries, such massive overwork by women or high accident rates ${ }^{11}$. Posing 
socialism against capitalism seems a bit outmoded, like asking the wrong questions after socialism's massive failure. In Scandinavia already those things exist that socialism is supposed to give to women but has not usually delivered.

The short chapter on Feminist Art in Taiwan by Richard C. Kagan after a brief, but informative introduction only four female artists are presented which feels like a few more would essentially have substantiated the introduction.

Together these two books give a comprehensive introduction to women and gender in Taiwanese modern development with some useful comparisons to China and some highlights on the importance of culture in explaining which particular type of capitalism evolves and shows how Taiwan and China though they have different political systems still have a common culture of degrading women leading to similar types of exploitation. Hence there would be a great cross-Strait learning potential.

\section{NOTES}

1. Marina Thorborg, Korea Program on Women, United Nations Industrial Development Association, UNIDO, Vienna, 1991, 146 pp.

2. Juliette Li, “The Pearl River Delta migrant labour shortage" in CSR Asia Weekly, Vol. 1, Week 9, p. 2, and Mei Fong, "A Chinese Puzzle", The Wall Street Journal, August $16^{\text {th }}$ 2004, and "Labour shortage in Pearl River Delta", www.amrc.org.hk/5210.htm, April $13^{\text {th }} 2005$.

3. Janet Salaff, Working Daughters of Hong Kong, New York, Columbia University Press, 1995.

4. Ester Ngan-ling Chow (ed.), Transforming Gender and Development in East Asia, New York, Routledge, 2002.

5. Oxfam Hong Kong Briefing Paper, "Turning the Garment Industry Inside Out Purchasing Practises and Workers' Lives", Oxfam, Hong Kong, 2004.

6. Stephanie Seguino, "Gender, Quality of Life, and Growth in Asia, 1970-90", The Pacific Review, Vol. 15, No. 2, 2002, pp. 245-277, and Lawrence Haddad, “Women's Status ! Levels, Determinants, Consequences for Malnutrition, Interventions, and Policy", in Asian Development Review, Vol. 17, No. 1, 1999, pp. 96-131.

7. Pun Ngai, Made in China Women Factory Workers in a Global Workplace, Durham and London, Duke University Press, and Hong Kong, Hong Kong University Press, “ 2005, and Ching Kwan Lee, Gender and the South China Miracle, Berkeley, Los Angeles, London, University of California Press, 1998.

8. Valerie M. Hudson, Andrea M. den Boer, Bare Branches Security Implications of Asia Surplus Male Population, Cambridge, Mass., London, MIT Press, 2004.

9. Ronald Inglehart and Pippa Norris, Rising Tide! Gender Equality and Cultural Change around the World, Cambridge, Cambridge University Press, 2003.

10. Marina Thorborg, "Chinese Employment Policy in 1949-78 With Special Emphasis on Women in Rural Production", in Chinese Economy Post-Mao, Joint Economy 
Committee, Congress of the United States, US Government Printing Office, Washington D.C., 1978.

11. Marina Thorborg, "Work and Unemployment" and "Women and Gender in the History of the Baltic Region", in Witold Maciejewski (ed.), The Baltic Sea Region Culture, Politics, Society, The Baltic University Programme, Uppsala University, 2002, pp. 401-414 and pp. 431-444. Marina Thorborg, "Latvian Women in a Comparative Framework", in Marina Thorborg and Inna Bronislava Zarinna (eds.), Gender Equality in Latvia at the Threshold of the New Millennium, Riga, Latvian Academy of Sciences, 2000, pp. 10-23. 